\title{
The Response of Mustard (Brassica juncea L.) on the Applying of Fish Flour Fertilizer
}

\author{
Idwar, Isna Rahma Dini*, Hariyanti \\ Department of Agrotechnology-Agriculture Faculty, Universitas Riau \\ Riau, Indonesia \\ *Corresponding author's email: isnarahmadini19 [AT] gmail.com
}

\begin{abstract}
The desired vegetable products are vegetables which are of good quality, healthy and safe for consumed, so that it needs to be done sustainable. Sustainable agriculture can only be achieved with sustainable soil productivity by maintaining soil organic matter content. The provision of organic fish meal as an alternative is more guaranteed for mustard. The aim of this study was to determine the response of mustard on the application of fish flour fertilizer and gain the best treatment in increasing the growth and production of mustard and to observe the effect of the remaining fish flour at the first planting. This research was carried out in the Experimental Garden of the Agriculture Faculty, Universitas Riau. This study was carried out experimentally by using a completely randomized design consisting of 9 treatments, namely To (without fish meal fertilizer), T1 (0.5 g per plant), T2 (1.0 g per plant), T3 (1.5 g per plant), T4 (2.0 $\mathrm{g}$ per plant), $T 5$ (2.5 $\mathrm{g}$ per plant), 66 (3.0 $\mathrm{g}$ per plant), 77 (3.5 $\mathrm{g}$ per plant) and $\mathrm{T} 8$ (4.0 $\mathrm{g}$ per plant). The parameters observed were plant height, number of leaves, leaf area, fresh weight of plants and fresh weight of plants suitable for consumption. The Applying of 4.0 $g$ fish flour per plant showed the best results for all parameters. The residual effect of giving fish flour is not sufficiently available for growth and the production of mustard in the second planting looks lower compared to the first planting.
\end{abstract}

Keywords- Fish flour, Brassica juncea L., residual effect

\section{INTRODUCTION}

The demand for organic agricultural products in developed countries is increasing every year [1]. This increase in demand is driven by people's lifestyles, the benefits of organic farming and the importance of environmental health as well as the support of the modern market which absorbs $50 \%$ of organic products. One of the organic agricultural products that are quite in demand by the community is vegetables. Vegetable products that consumers want are vegetables that are of good quality and healthy and safe for consumption, so that the application of organic fertilizers is recommended for vegetable cultivation, one of which is mustard.

Mustard is a plant that is widely cultivated in Indonesia because it can be developed in highland and lowland areas [2]. Riau is a lowland area so that the cultivation of organic mustard has a great opportunity to be developed. In addition, Riau is also a fairly large fishing area where almost every area in Riau has fishery potential, both capture fisheries and aquaculture, so there is a great opportunity for the development of organic fertilizer from fish flour. Fish flour is a processed commodity of aquatic products obtained from raw materials into a product consisting mostly of fish protein components. The raw material used in the manufacture of fish flour comes from trash fish. Trash fish is a by-product of the main fish processing or from by-catch which is considered to have no economic value, so it tends not to be processed and disposed of by processors or fishermen. This type of fish has a fairly high protein content, so it can be used to be processed into a value-added product. One solution that can be done is to use trash fish as raw material for fish flour. Fish flour has a high enough nutrient content to be used as organic fertilizer. Based on the results of the analysis, trash fish flour contains $10 \% \mathrm{~N}, 7.04 \% \mathrm{P}$ and $0.56 \% \mathrm{~K}$ [3].

The use of fish flour for vegetable crop cultivation has also been carried out by [4] which states that dead fish flour taken from the Cirata reservoir fisheries waste shows that the fish flour produced is quite potential as a source of nitrogen and phosphorus to be used as organic fertilizer because it contains total $\mathrm{N}$ and high $\mathrm{P}$, namely N 9.63\% and P 3.26\%. Land kangkung (Ipomea reptana) which was applied with fish flour gave the best response to the growth rate of plant height, number of leaves and wet weight of harvest with the addition of $30 \%$ fish flour compared to the addition of $40 \%$ - $100 \%$ fish flour and the application of inorganic fertilizers (1,4 $\mathrm{g} \mathrm{Urea}, 2,3 \mathrm{~g} \mathrm{SP} 36$ dan $0,8 \mathrm{~g} \mathrm{KCl})$. In addition, fertilizer made from fish is rich in macro and micro elements [5]. 
This study aims to determine the response of mustard plants to the provision of fish meal. Getting the best treatment in increasing the growth and production of mustard and seeing the effects of fish flour residue on the second planting.

\section{MATERIALS AND METHODS}

This research was conducted experimentally using a completely randomized design (CRD) consisting of 9 treatments and 3 replications so that 27 experimental units were obtained, each experimental unit consisted of 25 plants and 3 of them were used as sample plants from each unit.

The treatments used are as follows: $\mathrm{T}_{0}$ : Without fish flour fertilizer, $\mathrm{T}_{1}: 0,5 \mathrm{~g}$ per plant $\left(12,5 \mathrm{~g}^{\mathrm{p}} \mathrm{plot}^{-1}\right), \mathrm{T}_{2}: 1,0 \mathrm{~g}$ per plant $\left(25 \mathrm{~g}\right.$. plot $\left.{ }^{-1}\right), \mathrm{T}_{3}: 1,5 \mathrm{~g}$ per plant $\left(37,5 \mathrm{~g}\right.$. plot $\left.{ }^{-1}\right), \mathrm{T}_{4}: 2,0 \mathrm{~g}$ per plant $\left(50 \mathrm{~g} \cdot\right.$ plot $\left.^{-1}\right), \mathrm{T}_{5}: 2,5 \mathrm{~g}$ per plant $\left(62,5 \mathrm{~g} \cdot\right.$ plot $\left.^{-1}\right), \mathrm{T}_{6}: 3,0 \mathrm{~g}$ per plant $\left(75 \mathrm{~g}\right.$. plot $\left.^{-1}\right), \mathrm{T}_{7}: 3,5 \mathrm{~g}$ per plant $\left(87,5 \mathrm{~g}\right.$. plot $\left.^{-1}\right), \mathrm{T}_{8}: 4,0 \mathrm{~g}$ per plant $\left(100 \mathrm{~g}\right.$. plot $\left.{ }^{-1}\right)$.

The parameters observed were height of plant, number of leaves, leaf area, fresh weight plant, and fresh weight of plants suitable for consumption. The data obtained were analyzed statistically using variance. The results of the variance were continued with Duncan's multiple distance test at 5\% level.

\section{RESULT AND DISCUSSION}

\subsection{Height of Plant}

The results of variance showed that the application of fish flour had a significant effect on the height of the mustard plant, both in the first and second plantings. The results of the DNMRT further test at the 5\% level can be seen in Table 1.

Table 1 The average of the mustard height in the various doses of fish flour at the first and the second planting.

\begin{tabular}{ccc}
\hline \multirow{2}{*}{ Fish flour (g/plant) } & \multicolumn{2}{c}{ The average of the plant height $(\mathrm{cm})$} \\
\cline { 2 - 3 } & Firs planting & Second planting \\
\hline 4,0 & $35,57 \mathrm{a}$ & $22,32 \mathrm{a}$ \\
3,5 & $30,01 \mathrm{~b}$ & $21,68 \mathrm{ab}$ \\
2,5 & $25,18 \mathrm{c}$ & $21,34 \mathrm{bc}$ \\
2,0 & $24,07 \mathrm{~cd}$ & $20,85 \mathrm{~cd}$ \\
1,5 & $23,48 \mathrm{~cd}$ & $20,10 \mathrm{de}$ \\
1,0 & $23,20 \mathrm{~cd}$ & $19,42 \mathrm{ef}$ \\
0,5 & $22,93 \mathrm{~cd}$ & $18,82 \mathrm{f}$ \\
Without fish flour & $20,78 \mathrm{~d}$ & $18,72 \mathrm{f}$ \\
\end{tabular}

Note: The numbers followed by the same lowercase letter in the same column are not significantly different according to the DNMRT test at the $5 \%$ level.

Table 1 shows that the application of fish flour at the first planting resulted in better growth of mustard plant height than without fish flour. Mustard plants that were given fish flour 4,0 g per plant showed the highest plant height of $35,57 \mathrm{~cm}$, while the treatment without fish flour showed the lowest plant height of $17,05 \mathrm{~cm}$. The application of fish flour 4,0 g per plant and $3,5 \mathrm{~g}$ per plant was significantly different in increasing plant height compared to all treatments.

Table 1 also shows that the second planting showed better plant height than without fish meal. Mustard plants that were given fish flour $4,0 \mathrm{~g}$ per plant showed the highest plant height of $22,32 \mathrm{~cm}$, while the treatment without fish flour showed the lowest plant height of $16,97 \mathrm{~cm}$. The application of fish flour 4,0 g per plant was significantly different compared to all treatments, but not significantly different compared to the fish flour treatment of $3,5 \mathrm{~g}$ per plant.

Plant height is a parameter that is often observed as an indicator of growth as well as a parameter to measure the influence of the environment or the treatment applied because plant height is the easiest measure of growth to see. Height is the vertical growth of the plant and changes every day [6]. Nitrogen is a nutrient in the soil that plays a very important role in the growth of mustard plants. The supply of $\mathrm{N}$ elements through fertilization is preferred because $\mathrm{N}$ is the element that is most often lost from the land after harvesting. Plants that lack $\mathrm{N}$ will continue to shrink, even quickly turning yellow because there is not enough $\mathrm{N}$ available to form protein and chlorophyll [7] More than $98 \%$ of the $\mathrm{N}$ present in the soil is not available to plants because it accumulates in organic matter or becomes entangled in clay minerals. The application of fish flour $4,0 \mathrm{~g}$ per plant- 
contains more nutrients and was able to meet the nutrient needs of mustard plants. The $10 \%$ nitrogen contained in trash fish flour is able to meet the nutrient needs of mustard plants. The element $\mathrm{N}$ plays a role in stimulating vegetative growth in plants, one of which is in increasing plant height. Therefore, optimal nitrogen application can increase plant growth rate. In the vegetative growth phase, plants need a lot of $\mathrm{N}$, especially for the formation of stems and leaves.

[4] added that the application of $100 \%$ fish flour without the addition of other organic materials contained higher N. The greater the proportion of fish flour added, the greater the total nitrogen content produced. This is in accordance with the statement of [8] which states that the higher the nitrogen content of the added raw materials, the easier the decomposition rate will result in a high total nitrogen value. The element nitrogen plays an important role in the formation of protein compounds and chlorophyll. In addition, in trash fish flour there is also a P content of $7.04 \%$ and $\mathrm{K} 0.56 \%$ which is very influential for the growth of mustard plants [3]. Treatment without fish flour showed the lowest plant height, because the plants did not get additional nutrient intake which only depended on nutrients from the soil. Sufficient nutrients will support plant growth, but if the soil is not able to meet plant needs, growth will be stunted and even die due to lack of nutrients [9].

\subsection{Number of Leaves}

The results of the variance showed that fish flour had a significant effect on the number of leaves of mustard plants in both the first and second plantings. The results of the DNMRT further test at the $5 \%$ level can be seen in Table 2 .

Table 2 The average number of mustard leaves in the various doses of fish flour at the first and the second planting.

\begin{tabular}{ccc}
\hline \multirow{2}{*}{ Fish flour (g/plant) } & \multicolumn{2}{c}{ The average on the Number Leaves (sheet) } \\
\cline { 2 - 3 } & First planting & Second planting \\
\hline 4,0 & $18,44 \mathrm{a}$ & $11,77 \mathrm{a}$ \\
3,5 & $15,88 \mathrm{~b}$ & $11,22 \mathrm{a}$ \\
3,0 & $15,55 \mathrm{bc}$ & $9,88 \mathrm{ab}$ \\
2,5 & $15,00 \mathrm{bc}$ & $9,88 \mathrm{ab}$ \\
2,0 & $14,44 \mathrm{bcd}$ & $8,66 \mathrm{~b}$ \\
1,5 & $14,11 \mathrm{~cd}$ & $8,55 \mathrm{~b}$ \\
1,0 & $13,22 \mathrm{de}$ & $8,11 \mathrm{~b}$ \\
0,5 & $13,00 \mathrm{de}$ & $7,88 \mathrm{~b}$ \\
Without fish flour & $12,22 \mathrm{e}$ & $7,77 \mathrm{~b}$ \\
\hline
\end{tabular}

Note: The numbers followed by the same lowercase letter in the same column are not significantly different according to the DNMRT test at the $5 \%$ level.

Table 2 shows that the application of fish flour at the first planting resulted in a better number of mustard leaves than without fish flour. Mustard plants that were given fish flour 4,0 g per plant showed the highest number of leaves, namely 18,44 sheet, while the treatment without fish flour showed the lowest number of leaves, namely 12,22 sheet. The application of fish flour 4,0 g per plant, was significantly different compared to all treatments. Likewise, the application of 3,5 g per plant was significantly different in the growth of the number of mustard leaves compared to all treatments, but not significantly compared with the treatment of fish flour 3,0 g per plant, 2,5 g per plant and 2,0 g per plant.

Table 2 also shows that the application of fish flour on the second planting showed a better growth in the number of leaves than without fish flour. Mustard plants that were given fish flour 4,0 g per plant showed the highest number of leaves, namely 11,77 sheet, while the treatment without fish flour showed the lowest number of leaves, which was 7,77 sheet. The application of fish flour 4,0 g per plant, significantly different with treatments 2,0 g per plant, $1,5 \mathrm{~g}$ per plant, 1,0 g per plant, $0,5 \mathrm{~g}$ per plant and without fish flour, but not significantly different with the treatment of fish flour $3,5 \mathrm{~g}$ per plant, 3,0 g per plant and 2,5 g per plant.

Leaves are a place for plant organs to synthesize food for plant needs and as food reserves. Leaves have chlorophyll which plays a role in carrying out photosynthesis, the more the number of leaves, the more places to carry out the photosynthesis process and better results. The increase in the number of leaves is one form of growth which is measured meristically (by number).

The application of fish flour on the second planting was only slightly available at the treatment of 4,0 g per plant and 3,5 $\mathrm{g}$ per plant while the other treatments were not sufficient for the growth of the number of leaves. This is because the nutrients in the second planting only come from the soil, which is thought to be unable to meet the nutrient requirements needed by the mustard plant until the end of the planting period so that the number of leaves that grow becomes small and growth is stunted 
because it only depends on limited nutrients from soil that is not given fertilizer. The number of leaves indicates plant growth, the more the number of leaves produced, the better the plant growth.

The nutrient content contained in trash fish flour is thought to be able to provide sufficient nutrient intake for the growth of the number of plant leaves. The nutrient content of $\mathrm{N}(10 \%)$ of fish flour was able to meet the growth of mustard plants during the vegetative phase. In addition, the nutrient content of $\mathrm{P}(7.04 \%)$ contained in trash fish also has a very important effect as an energy source. Trash fish has a high protein content so it can be used as a source of phosphorus.

[4] stated that the application of $100 \%$ fish flour without the addition of other organic materials contained higher P. In addition to the $\mathrm{N}$ and $\mathrm{P}$ content in fish flour, there is also an elemental $\mathrm{K}(0.56 \%)$ which is beneficial for mustard plants, the potassium content in fertilizer plays a very important role in the growth of the number of plant leaves. [10] stated that potassium is also able to increase the development of plant roots and leaves. Potassium plays an important role in the process of opening stomata which can affect the rate of photosynthesis of mustard plants, the formation of proteins and carbohydrates. Potassium plays a role in the formation of proteins and carbohydrates, hardening the woody parts of plants, and improving the quality of seeds and fruit. Elemental $\mathrm{K}$ is absorbed in the form of $\mathrm{K}+$, especially in young plants [11].

[4] stated that the addition of fish flour in the manufacture of bokashi fertilizer also affected the growth of the number of leaves of the land kale (Ipomea reptana). This is because the bokashi fertilizer produced is able to provide sufficient potassium intake for the growth of the number of leaves of land kale plants. Mustard plants in the treatment without fish flour experienced obstacles in the formation of plant leaves. This is due to the non-fulfillment of nutrient requirements for the growth of mustard plants.

\subsection{Leaf Area}

The results of the variance showed that fish flour had a significant effect on leaf area of mustard plants in both the first and second plantings. The results of the DNMRT further test at the 5\% level can be seen in Table 3.

Table 3 The average on the leaf area of the mustard in the various doses of fish flour at the first and the second planting.

\begin{tabular}{ccc}
\hline \multirow{2}{*}{ Fish flour (g/plant) } & \multicolumn{2}{c}{ The average on the of leaf area $\left(\mathrm{cm}^{2}\right)$} \\
\cline { 2 - 3 } & First planting & Second planting \\
\hline 4,0 & $239,43 \mathrm{a}$ & $230,22 \mathrm{a}$ \\
3,5 & $231,76 \mathrm{a}$ & $222,54 \mathrm{a}$ \\
3,0 & $184,17 \mathrm{~b}$ & $197,99 \mathrm{~b}$ \\
2,5 & $184,16 \mathrm{~b}$ & $188,78 \mathrm{~b}$ \\
2,0 & $147,33 \mathrm{c}$ & $135,06 \mathrm{c}$ \\
1,5 & $139,66 \mathrm{c}$ & $119,71 \mathrm{~d}$ \\
1,0 & $122,78 \mathrm{~d}$ & $115,11 \mathrm{~d}$ \\
0,5 & $108,96 \mathrm{de}$ & $113,57 \mathrm{~d}$ \\
Without fish flour & $96,66 \mathrm{e}$ & $99,75 \mathrm{e}$ \\
\hline
\end{tabular}

Note: The numbers followed by the same lowercase letter in the same column are not significantly different according to the DNMRT test at the 5\% level.

Table 3 shows that the application of fish flour at the first planting resulted in better leaf area of mustard plants than without fish flour. Mustard plants that were given fish flour 4,0 g per plant showed the highest leaf area of $239,43 \mathrm{~cm}^{2}$, while the treatment without fish flour showed the lowest leaf area of $96,66 \mathrm{~cm}^{2}$. The application of fish flour $4,0 \mathrm{~g}$ per plant was significantly different compared to all treatments but not significantly different from the fish flour treatment of 3,5 g per plant. Likewise, giving 3,0 g per plant was significantly different in increasing the area of mustard leaf area compared to all treatments, but not significantly different from the fish flour treatment of 2,5 g per plant. The application of fish flour $2,0 \mathrm{~g}$ per plant was also significantly different compared to all treatments but not significantly different from the treatment of $1,5 \mathrm{~g}$ per plant. Likewise, giving fish flour $1,0 \mathrm{~g}$ per plant was significantly different in increasing the area of mustard leaf area compared to all treatments, but not significantly different from fish flour $0.5 \mathrm{~g}$ per plant.

Table 3 also shows that the application of fish flour on the second planting showed better leaf area growth than without fish flour. Mustard plants that were given fish flour 4,0 g per plant showed the highest leaf area of $230.22 \mathrm{~cm}^{2}$, while the treatment without fish flour showed the lowest leaf area of $99,75 \mathrm{~cm}^{2}$. The application of fish flour 4,0 g per plant was significantly different compared to all treatments but not significantly different from the treatment of $3,5 \mathrm{~g}$ per plant. Likewise, giving 3,0 $\mathrm{g}$ 
per plant was significantly different in increasing the area of mustard leaf compared to all treatments, but it was not significantly different from the treatment of 2,5 g per plant. The application of 2,0 g fish flour per plant was also significantly different compared to all treatments and 1,5 g fish flour per plant was also significantly different in increasing leaf area compared to all treatments but not significantly compared to $0,5 \mathrm{~g}$ fish flour treatment per plant, $1,0 \mathrm{~g}$ per plant and $1,5 \mathrm{~g}$ per plant. The growth of leaf area given fish flour showed the highest yield compared to without fish flour. It is suspected that fish flour is able to provide adequate nutrient intake for the growth of leaf area.

Nitrogen is more optimum in supporting the growth of the vegetative part than the generative part and it is important for vegetable plants that are consumed by the canopy. According to [12], plants that get enough $\mathrm{N}$ sulpai will form broad leaf blades with high chlorophyll content so that plants can produce assimilate in sufficient quantities to support their vegetative growth. Application of nitrogen in sufficient quantities, can produce large leaf size. In addition, the nutrient content contained in fish flour is able to provide additional phosphorus and potassium content in supplying nutrients for the growth of mustard plants. The nutrient content of $\mathrm{N}(10 \%), \mathrm{P}(7,04 \%)$ and $\mathrm{K}(0,56 \%)$ contained in fish flour is able to supply the needs of mustard plants for growth in height, number of leaves and leaf area of plants.

[13] added that the application of liquid organic fertilizer from trash fish waste was able to meet the growth in length or area of spinach and kale leaves. The quality of liquid organic fertilizer from fish waste is more effective in supporting the growth of leaf length and area compared to without using liquid fertilizer from fish waste. In addition, [14] also stated that the treatment of fish waste liquid fertilizer had an effect on observing plant length and observing the number of leaves.

\subsection{Fresh Weight Plant}

The results of the variance showed that fish flour had a significant effect on the fresh weight of mustard plants in both the first and second plantings. The results of the DNMRT further test at the 5\% level can be seen in Table 4 .

Table 4. The average of fresh weight plants in mustard in the various doses of fish flour at the first and the second planting

\begin{tabular}{ccc}
\hline \multirow{2}{*}{ Fish flour (g/plant) } & \multicolumn{2}{c}{ The average of weight fresh plants $(\mathrm{g})$} \\
\cline { 2 - 3 } & First planting & Second planting \\
\hline 4,0 & $294,42 \mathrm{a}$ & $258,33 \mathrm{a}$ \\
3,5 & $277,78 \mathrm{ab}$ & $166,67 \mathrm{~b}$ \\
2,0 & $263,89 \mathrm{abc}$ & $141,67 \mathrm{bc}$ \\
2,0 & $227,78 \mathrm{abcd}$ & $125,00 \mathrm{~cd}$ \\
1,0 & $211,11 \mathrm{bcde}$ & $113,89 \mathrm{~cd}$ \\
1,5 & $197,22 \mathrm{cde}$ & $105,56 \mathrm{de}$ \\
0,5 & $188,06 \mathrm{de}$ & $100,00 \mathrm{de}$ \\
Without fish flour & $147,22 \mathrm{~d}$ & $94,44 \mathrm{de}$ \\
\end{tabular}

Note: The numbers followed by the same lowercase letter in the same column are not significantly different according to the DNMRT test at the $5 \%$ level.

Table 4 shows that the application of fish flour at the first planting resulted in a better fresh weight of mustard plants than without fish flour. Mustard plants that were given fish flour 4,0 g per plant showed the highest fresh weight of 294,42 g, while the treatment without fish flour showed the lowest fresh weight of $138,90 \mathrm{~g}$. The application of fish flour 4,0 g per plant was significantly different compared to all treatments, but not significantly different from the fish flour treatments at $3,5 \mathrm{~g}$ per plant, $3,0 \mathrm{~g}$ per plant and $2,5 \mathrm{~g}$ per plant.

Table 4 also shows that the application of fish flour at the second planting showed a better growth in fresh weight of mustard plants than without fish flour. Mustard plants that were given fish flour 4,0 g per plant showed the highest plant fresh weight of $258,33 \mathrm{~g}$, while the treatment without fish flour showed the lowest plant fresh weight of 80,55 g. The application of fish flour 4,0 g per plant, was significantly different compared to all treatments. Likewise, the fresh weight of mustard plant of application fish flour of 3,5 g per plant was significantly different compared to all treatments, but not significantly different from the treatment of fish flour 3,0 g per plant.

[15] stated that plants that receive sufficient supply of $\mathrm{N}$ will form broad leaves with high chlorophyll content, so that plants are able to produce carbohydrates in sufficient quantities for plant vegetative growth such as plant height, and the formation of 
new leaves, so that fresh weight plant will also increase. Comparison of the right composition of organic fertilizer raw materials will produce fertilizers that have good quality and can be easily utilized by plants [16].

Nitrogen is the main macro nutrient that is needed by plants. This element is called the primary macro element because it is the most important in the plant life cycle [17]. Nitrogen is also an element that plants need in high amounts after the elements hydrogen, carbon and oxygen as the building blocks of the plant body.

Marine fish waste as an additional source of organic matter plays an important role in plant growth. Soil organic matter has a very important role in soil, especially in soil fertility, physical, chemical, and biological properties which are directly or indirectly influenced by soil organic matter [18].

[4] stated that the application of bokashi fertilizer with the addition of fish flour has good potential to replace the role of inorganic fertilizers, supported by the nature of organic fertilizers that can improve soil structure. The function of organic matter as forming soil physical fertility is very important and cannot be replaced by other components available in nature. [19] stated that the addition of organic matter in mustard plants affected plant height, leaf area, root dry weight, leaf dry weight and relative growth rate.

\subsection{Fresh Weight of Plants Suitable for Consumption}

The results of variance showed that fish flour had a significant effect on the fresh weight of plants suitable for consumption by mustard plants, both in the first and second plantings. The results of the DNMRT further test at the 5\% level can be seen in Table 5 .

Table 5. The average of fresh weight of mustard plants suitable for consumption in the various doses of fish flour at the first and the second planting

\begin{tabular}{ccc}
\hline \multirow{2}{*}{ Fish flour (g/plant) } & The average of weight fresh plants suitable for consumption $\left(\mathrm{g} \cdot \mathrm{m}^{2}\right)$ \\
\cline { 2 - 3 } & First planting & Second planting \\
\hline 4,0 & $3600 \mathrm{a}$ & $2000 \mathrm{a}$ \\
3,5 & $3066 \mathrm{ab}$ & $1483 \mathrm{~b}$ \\
3,0 & $2633 \mathrm{bc}$ & $1333 \mathrm{bc}$ \\
2,5 & $2350 \mathrm{~cd}$ & $1300 \mathrm{~cd}$ \\
2,0 & $2200 \mathrm{~cd}$ & $1266 \mathrm{~cd}$ \\
1,5 & $2000 \mathrm{~cd}$ & $1183 \mathrm{cde}$ \\
1,0 & $1733 \mathrm{de}$ & $1133 \mathrm{de}$ \\
0,5 & $1266 \mathrm{e}$ & $1033 \mathrm{e}$ \\
Without fish flour & $1116 \mathrm{e}$ & $866 \mathrm{f}$ \\
\hline
\end{tabular}

Note: The numbers followed by the same lowercase letter in the same column are not significantly different according to the DNMRT test at the $5 \%$ level.

Table 5 shows that the application of fish flour at the first planting resulted in better fresh weight of plants suitable for consumption than without fish flour. Mustard plants that were given fish flour 4,0 g per plant showed the highest fresh weight of plants suitable for consumption was $3600 \mathrm{~g}$, while the treatment without fish flour showed the lowest was $1116 \mathrm{~g}$. The application of fish flour 4,0 g per plant was significantly different compared to all treatments, but not significantly different from the fish flour treatment of $3,5 \mathrm{~g}$ per plant.

Table 5 also shows that the application of fish flour at the second planting showed a better growth in fresh weight of plants suitable for consumption than without fish flour. Mustard plants that were given fish flour 4,0 g per plant showed the highest fresh weight of plants suitable for consumption, namely $2000 \mathrm{~g}$, while the treatment without fish meal showed the lowest fresh weight of plants suitable for consumption, namely $866 \mathrm{~g}$. The application of fish flour $4,0 \mathrm{~g}$ per plant, was significantly different compared to all treatments. Likewise, the application of 3,5 g per plant was significantly different in the fresh weight of mustard plants suitable for consumption compared to all treatments, but not significantly different from the fish flour of $3,0 \mathrm{~g}$ per plant.

Fresh weight of plants suitable for consumption is the net weight that can be consumed from the fresh weight of plants without including damaged and withered roots and leaves. According to [20], fresh weight of plant is also related to plant height, number of leaves, and leaf area. The large number of leaves, leaf area and plant height will produce more photosynthate so that it will increase the fresh weight of consumption. 
Fresh weight of plants suitable for consumption on the second planting, there was a decrease in yield. The decrease in mustard yield in the second planting was thought the value of the $\mathrm{C} / \mathrm{N}$ ratio contained in fish flour was still low. The $\mathrm{C} / \mathrm{N}$ ratio is an indicator value that shows the process of mineralization-immobilization of nutrients by microbial decomposers of organic matter [21]. If the amount of $\mathrm{C}$-organic content is low and the nitrogen content is high, then the $\mathrm{C} / \mathrm{N}$ ratio will be low [22].

Trash fish flour has a $\mathrm{C} / \mathrm{N}$ ratio of 4,36 . Based on this value, the value of the $\mathrm{C} / \mathrm{N}$ ratio of the organic fertilizer produced does not meet the value of the $\mathrm{C} / \mathrm{N}$ ratio according to SNI 19-7030-2004, namely $10-20$. The low value of the $\mathrm{C} / \mathrm{N}$ ratio in the fish flour produced can be caused by the raw materials used for fertilizer production has a very high nitrogen content [23]. The low value of $\mathrm{C} / \mathrm{N}$ ratio can also be caused by the nitrogen loss process that is not optimal. [23] stated that in fertilizers that have a low $\mathrm{C} / \mathrm{N}$ ratio or the use of nitrogen-rich raw materials, there will be a process of losing nitrogen into ammonia (NH3). This occurs as a result of excess nitrogen that is not utilized by microbes. If the value of the $\mathrm{C} / \mathrm{N}$ ratio is too low due to nitrogenrich raw materials, then carbon will become a limiting nutrient or nutrient absorption activity will be hampered and limited by carbon content. A C/N ratio that is too low can also inhibit the absorption of other nutrients so that it can inhibit plant growth.

The application fish flour 4,0 g per plant showed better growth in plant height, increase in leaf number, leaf area, fresh weight of plant and fresh weight of plant suitable for consumption. This indicates that fish flour 4,0 g per plant with a nutrient content of $10 \% \mathrm{~N}, 7.04 \% \mathrm{P}$ and $0.56 \% \mathrm{~K}$ was able to meet the nutrient needs of mustard plants. The treatment without fish flour showed the lowest fresh weight of plant suitable for consumption. This is because the availability of nutrients in plants is limited, plants only utilize nutrients available in the soil, so that physiological processes in plants cannot run properly and result in slow plant growth.

[24] stated that fish waste can be used as raw material for making organic fertilizers. The application of organic fertilizers can improve the physical, chemical and biological properties of the soil. Utilization of fish waste in addition to the potential to be used as organic fertilizer also plays a role in reducing environmental pollution caused by fish processing waste that is thrown away without regard to its negative impact on the environment [25]. Utilization of fish waste into organic fertilizer aims to produce fertilizers that are rich in various nutrients needed by plants and overcome the scarcity of fertilizers [26]. Apart from being a source of nutrients, fish-based fertilizers were reported to significantly reduce the attack of the pathogens Macrophomina phaseolina, Rhizoctonia solani and Fusarium spp., on okra and long beans [27].

\section{CONCLUSIONS}

The application of fish flour can increase the growth and production of mustard plants, as seen in the parameters of plant height, number of leaves, leaf area, fresh weight of plants and fresh weight of plants suitable for consumption. The application of fish flour 4,0 g per plant showed the best results for all parameters in both the first and second plantings. The residual effect of giving fish flour was not sufficient for the growth and production of mustard plants, the second planting decreased compared to the first planting.

\section{REFERENCES}

[1] Horticultural Production Statistics, "Horticultural production statistics 2011", Ministry of Agriculture Directorate General of Hortculture, 2011.

[2] Ngantung, J.A.B., J.J. Rondonuwu and R.I. Kawulusan, "Response of mustard green (Brassica juncea L.) to application of organic and inorganic fertilizer in Kelurahan Tomohon Timur, District Rurukan", Eugenia, vol. 24, no.1, pp. 44-52, 2018.

[3] Hariyanti, "The results of the analysis of Hariyanti trash fish flour". Faculty of Agriculture, Riau University, Pekanbaru, 2018.

[4] Syukron, F, "Making organic bokashi fertilizer from fish flour from the Cirata Reservoir fishery waste", Jurnal Penelitian Pertanian, vol. 6, no. 1, pp. 1-16, 2013.

[5] Lema, A and A. Degebassa, "Comparison of chemical fertilizer, fish offal's fertilizer and manure applied to tomato and onion”, African Journal of Agricultural Research, vol. 8, no. 3, pp. 274-278, 2013.

[6] Wasis, B. and A. Sandrasari, "Effect of compost fertilizer on the growth of mahogany (Swietenia macrophylla King.) seedlings on former gold mining soil media (tailings)", Jurnal Silvikultur Tropika, vol. 03, no. 01, 2011.

[7] Yuliarti, N, "1001 ways to produce organic fertilizer", Lily Publisher, Yogyakarta, 2009.

[8] Supadma, A.A.N. and D.M. Arthagama, "Test the formulation of the quality of compost sourced from organic waste with the addition of chicken, cow, pig and bitter plant waste", Jurnal Bumi Lestari, vol. 8, no. 2, pp. 113-121, 2008.

[9] Ruhnayat, A. "Determination of the basic needs for nutrients N, P, K for the growth of vanilla (Vanilla planifolia Andrews) glass, Indonesian Medicinal Plants Research Institute”, Bul. Littro, vol. 18, no. 1, pp. 49-59, 2007.

[10] Syakir, M. and G. Gusmaini, "The effect of the use of potassium fertilizer sources on the production and quality of 
patchouli oil”, Jurnal Penelitian Tanaman Industri, vol. 18, no. 2, pp. 60-65, 2012.

[11] Mulyadi, Y. Sudarno and E. Sutrisno, "Study of the addition of coconut water in the manufacture of liquid fertilizer from fish liquid waste on the macronutrient content of C, N, P, and K", Jurnal Penelitian dan Pengembangan Pertanian, vol. 1, no.1, pp. 1-14, 2013.

[12] Wijaya, K. "Effect of concentration and frequency of application of liquid organic fertilizer from anaerobic digestion of food waste on mustard plant growth (Brassica juncea L.)", Thesis of the Department of Biology, Faculty of Mathematics and Natural Sciences, Sebelas Maret University, Surakarta, pp. 1-55, 2010.

[13] Rengi, P. and Sumarto. "Technology study for utilization of fishery byproducts for making organic liquid fertilizer", pp. 48-55, 2014.

[14] Abror, M. and R.P. Harjo, RP. "The effectiveness of liquid organic fertilizer from fish waste and Trichoderma sp. on growth and yield", Jurnal Agrosains dan Teknologi, vol. 3, no. 1, 2018.

[15] Sanusi, A. and S.A. Adimihardja, "Growth and production of sweet mustard (Brassica juncea L.) at various doses of cattle compost and N, P and K fertilizers", Jurnal Agronida, vol. 1, no. 1, pp. 1-6, 2015.

[16] Widarti, B. Nining, Wardhini, W. Kusuma and E. Sarwono, "Effect of C/N ratio of raw materials on composting of cabbage and banana peels", Jurnal Integrasi Proses. vol. 5, no. 2, pp. 75-80, 2015.

[17] Utami, S.N.H. and Handayani, S, "Chemical properties of entisol in organic farming systems", Jurnal Ilmu Pertanian, vol. 3, no. 10, pp.63-69, 2003.

[18] Herman, D.Z, "The review of tailings contains pollutant elements Arsenic (As), Mercury (Hg), Lead (Pb), and Cadmium (Cd) from metal ore processing residues", Indonesian Journal on Geoscience, vol. 1, no. 1, pp. 31-36, 2014.

[19] Erawan, D. Yani, W. Ode and A. Bahrun, A, "Growth and yield of mustard (Brassica juncea L.) under various dosages of urea fertilizer", Jurnal Agroteknos, vol. 3, no. 1, pp. 19-25, 2013.

[20] Duaja, M.D, "Effect of ingredients and dosage of liquid compost on lettuce growth (Lactuca sativa sp)", Jurnal Agroteknologi Jambi, vol. 1, no. 1, pp. 19-25, 2012.

[21] Pramaswari, I.A.A., A.A.B. Putra and I.W.B. Suyasa, "Combination of organic matter (C/N ratio) in the treatment of sewage sludge", Jurnal Kimia, vol. 5, no. 1, pp. 64-71, 2015.

[22] Anita, G, "Manufacture of liquid fertilizer from traditional fish processing waste", Junal Envirotek, vol. 9, no. 2, 2012.

[23] Ismayana, A. Indrasti, N.S. Suprihatin, A. Maddu, and A. Fredy, "Initial C/N ratio factor and aeration rate in the cocomposting bagasse and blotong process", Jurnal Teknologi Industri Pertanian, vol. 22, no. 3, pp. 173-179, 2012.

[24] Ibrahim, B., P. Suptijah, and Y. Aktinidia, "Nutrient enrichment process of wasted fish from lake cirata by activators of Gliocladium sp . and kascing media", Jurnal Pengolahan Hasil Prikanan Indonesia, vol. 16, no. 1, 2013.

[25] Abbasi, P.A., D.A. Cuppels and G. Lazarovits, "Effect of foliar applications of neem oil and fish emulsion on bacterial spot and yield of tomatoes and peppers", Canadian Journal of Plant Pathology, vol. 25, no. 1, pp. 41-48, 2003.

[26] Hapsari, N. and T. Welasih, "Utilization of fish waste into organic fertilizer", Jurnal Teknik Lingkungan, vol. 1, no. 1, pp.1-6, 2015.

[27] Irshad, L., S. Dawar, and M.J. Zaki, "Effect of different dosages of nursery fertilizers in the control of root rot of okra and mung bean", Pakistan Journal of Botany, vol. 38, no. 1, pp. 217-223, 2006. 